\title{
Локальный спектральный анализ полупроводниковых нанокристаллов
}

\author{
А.Г.Милёхин ${ }^{1,2)}$, M.Rahaman ${ }^{3)}$, Т.А.Дуда ${ }^{1)}$, И.А.Милёхин ${ }^{1)}$, К.В.Аникин ${ }^{1)}$, Е.Е.Родякина ${ }^{1,2)}$, \\ P.Б. Васильев ${ }^{4)}$, V.M. Dzhagan ${ }^{4)}$, D.R.T. Zahn ${ }^{3)}$, A.B. Латышев ${ }^{1,2)}$ \\ ${ }^{I}$ Институт физики полупроводников им. А.В. Ржанова СО РАН, Новосибирск \\ ${ }^{2}$ Новосибирский государственный университет, Новосибирск \\ ${ }^{3}$ Semiconductor Physics, Chemnitz University of Technology, D-09107 Chemnitz, Germany \\ ${ }^{4}$ Московский государственный университет ии.М.В. Ломоносова, 119991, Москва \\ ${ }^{5}$ V.Ye. Lashkaryov Institute of Semiconductor Physics, Ukr. Nat. Acad. Sci., Kyiv 03028, Ukraine \\ тел:+7 (383) 330-2204, факс:+7 (383) 333-2771, эл.nочта: milekhin@isp.nsc.ru
}

DOI 10.34077/RCSP2019-39

Предложен новый метод локального спектрального анализа полупроводниковых наноструктур, основанный на обнаруженном гигантском комбинационное рассеяние света (КРС) полупроводниковыми наноструктурами, расположенными на поверхности массива нанокластеров $\mathrm{Au}$, вблизи металлизированного кантилевера атомно-силового микроскопа (АСM) (рис.1а).

В зазоре между металлическими нанокластерами и острием кантилевера АСМ микроскопа, где расположена полупроводниковая наноструктура, возникает сильное увеличение локального поля («горячая точка») и, как следствие, резкое усиление сигнала КРС.

В эксперименте наблюдается гигантское усиление сигнала КРС локализованными продольными и поверхностными оптическими фононами (LO и SO) в нанокристаллах (HK) CdSe (коэффициент усиления $10^{6}$ ). Картирование сигнала КРC на частоте оптических фононов CdSe позволило изучить эффекты локальных электромагнитных полей на фононный спектр нанокристаллов $\mathrm{CdSe}$ c пространственным разрешением 2 нм [1], определить фононный спектр отдельных нанокристаллов $\mathrm{CdSe}$ размером 6 нм [2], что находится далеко за дифракционным пределом (Рис.1б). Показано, что максимальное усиление сигнала наблюдается от торцов нанокластеров $\mathrm{Au}$, имеющих цилиндрическую форму (Рис.1б), где локальное электромагнитное поле максимально.

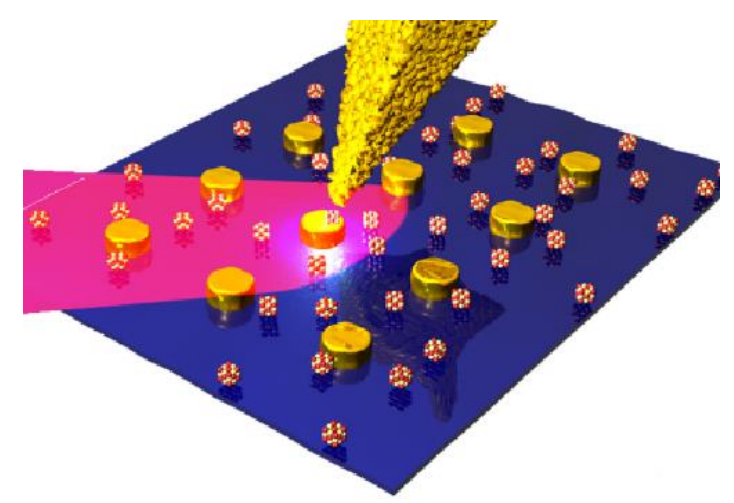

a)

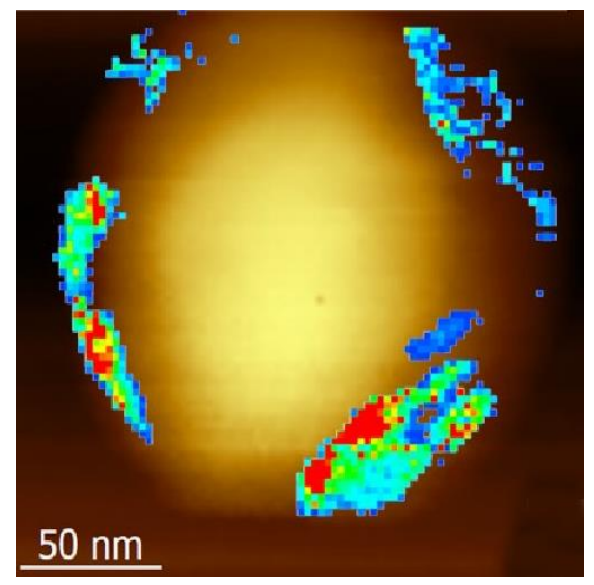

б)

Рис.1 а)- Схема эксперимента, демонстрирующая взаимное расположение нанокластеров $\mathrm{Au}, \mathrm{HK}$ $\mathrm{CdSe}$, металлизированной иглы ACM микроскопа и направления падающего лазерного излучения. б)- Карта интенсивности сигнала КРС HK CdSe на частоте LO фонона CdSe при 210 см$^{-1}$, совмещенная с АCM изображением той же области с одним нанокластером Au.

Обсуждаются механизмы активации мод поверхностных оптических фононов в спектрах КРС, записанных в условиях нано-КРС.

Исследование выполнено при финансовой поддержке РФФИ и Немецкого научноисследовательского сообщества в рамках научного проекта № 19-52-12041.

\section{Лumepamypa}

[1] V.M. Dzhagan, Yu.M. Azhniuk, A.G. Milekhin, D.R.T. Zahn // Journal of Physics D: Applied Physics, 2018. V.51, P.503001-1-50.

[2] M. Rahaman, A.G. Milekhin, A. Mukherjee, et al. // Faraday Discussions, (2018) accepted, DOI: 10.1039/C8FD00142A. 